\title{
Mediterranean and Atlantic deep-sea fish assemblages: differences in biomass composition and size-related structure*
}

\author{
ENRIC MASSUTÍ ${ }^{1}$, JOHN D.M. GORDON ${ }^{2}$, JOAN MORANTA³ ${ }^{3}$ SARAH C. SWAN², \\ CONSTANTÍ STEFANESCU ${ }^{4}$ and NIGEL R. MERRETT ${ }^{5}$ \\ ${ }^{1}$ IEO - Centre Oceanogràfic de les Balears, P.O. Box 291, 07080 Palma de Mallorca, Spain. \\ E-mail: enric.massuti@ba.ieo.es \\ ${ }^{2}$ Scottish Association for Marine Science, Dunstaffnage Marine Laboratory, Oban, Scotland, PA37 1QA, United Kingdom. \\ ${ }^{3}$ Institut Mediterrani d'Estudis Avançats (CSIC/UIB), Miquel Marquès 21, 07190 Esporles, Spain. \\ ${ }^{4}$ Museu de Granollers - Ciències Naturals, Francesc Macià 51, 08400 Granollers, Spain. \\ ${ }^{5}$ Muttlebury's Mead, Chard Street, Thorncombe, Chard TA20 4NB, United Kingdom.
}

SUMMARY: Data obtained over a period of twenty years from 214 bottom trawls, towed on a single warp at depths between 402 and $1993 \mathrm{~m}$ in the western Mediterranean (Algerian and Balearic basins) and eastern North Atlantic (Rockall Trough and Porcupine Seabight), allowed a standardised comparison of density, biomass composition and size-related structure for both the whole fish fauna and for the most common species found within the deep-sea fish assemblages. All four areas are characterised by distinctly different and well-documented oceanographic conditions, biogeographical affinities and fishing exploitation. The results showed clear differences between the Atlantic and the Mediterranean deep-sea fish fauna, not only in density, species richness and composition, but also in the structure of the biomass that constitutes these assemblages. These differences are discussed in relation to environmental conditions and fishing pattern, which have determined the adaptive responses of both individual species and the whole ecosystem.

Key words: deep-sea, fishes, community, biomass, size, western Mediterranean, NE Atlantic.

RESUMEN: COMUNIDADES DE PECES DE PROFUNDIDAD EN El MEDITERRÁNEO Y El ATLÁNTICO: DIFERENCIAS EN LA COMPOSICIÓN DE LA BIOMASA Y LA ESTRUCTURA DE TAMAÑOS. - Los datos obtenidos a partir de 214 pescas de arrastre de fondo con un sólo cable, realizadas a lo largo de un período de veinte años en el Mediterráneo occidental (cuencas argelina y balear) y Atlántico nor-oriental (Rockall Trough y Porcupine Seabight), entre 402 y 1993 m de profundidad, han permitido una comparación estandarizada de la densidad y de la composición y estructura de tamaños de la biomasa, tanto del conjunto de la ictiofauna como de las principales especies comunes en estas comunidades ícticas de gran profundidad. Estas cuatro áreas se caracterizan por diferencias, ampliamente documentadas, en sus condiciones oceanográficas, afinidades bio-geográficas y de explotación pesquera. Los resultados han mostrado claras diferencias entre la ictiofauna profunda atlántica y mediterránea, no sólo en términos de densidad, riqueza específica y composición, sino también en la estructura de la biomasa que compone estas comunidades. Estas diferencias se discuten en relación con las condiciones medio-ambientales y de explotación pesquera, las cuales han determinado las respuestas adaptativas, tanto de las especies individuales como del conjunto del ecosistema.

Palabras clave: mar profundo, peces, comunidad, biomasa, tamaño, Mediterráneo occidental, Atlántico NE. 


\section{INTRODUCTION}

Estimates of biomass and abundance give an indication of the role and relative importance of populations in food webs, including the amount of energy needed for maintenance (e.g. Platt, 1985; Bergmann, 1987). A knowledge of total abundance and biomass of deep-sea fauna and how these are partitioned among different functional and size categories can be a potentially useful approach for understanding trophic relationships and energy flow into and through these ecosystems (Thurston et al., 1994, Haedrich, 1996).

Furthermore, size distribution can provide information on the evolutionary responses of species and on community metabolism, and can also reflect the influence of fishing activity. However, there have been few studies of the species size and biomass spectra for deep-sea demersal fish assemblages. The only available information is from the Porcupine Seabight and the Madeira Abyssal Plain in the eastern North Atlantic (Haedrich and Merrett, 1992) and from the upper slope off southern Namibia in the southeastern North Atlantic (Macpherson and Gordoa, 1996).

In recent years, the deep-sea ichthyofauna of the Mediterranean Sea and the Atlantic Ocean has been extensively studied. In the western Mediterranean, both community structure (e.g. Stefanescu et al., 1993; Moranta et al., 1998) and distribution and biology of the main species have been studied (e.g. Massutí et al., 1995, 1996; Morales-Nin et al., 1996; Carrasón and Matallanas, 1998, 2001, 2002). In the eastern North Atlantic, there are also many publications, both on species composition and structure of assemblages (e.g. Merrett et al., 1991; Koslow, 1993) and the ecology of some dominant species (e.g. Mauchline and Gordon, 1984; Gordon and Duncan, 1985; Coggan et al., 1998; Allain, 2001).

From the results of the papers cited above, clear differences can be inferred between Mediterranean and Atlantic deep-sea fish assemblages. These differences are due not only to distinct species composition (e.g. Haedrich and Merrett, 1988; Stefanescu et al., 1993), but also to the maximum size of individual species (Tortonese, 1960; Stefanescu et al., 1992) . It is important to note, however, that misleading conclusions in comparative studies can arise from the use of different methodologies. Thus, in recent years, the importance of sampling gear when one is comparing fish assemblages has been demonstrated (e.g. Merrett et al., 1991; Gordon et al., 1996).
For this reason, our aim is to make a standardised comparison between biomass composition and sizerelated structure for both the whole fish assemblage and the most common species found in the deep sea of the western Mediterranean (Algerian and Balearic basins) and eastern North Atlantic (Rockall Trough and Porcupine Seabight). These areas are characterised by distinctly different and well-documented oceanographic conditions, surface productivity and seasonality, biogeographical affinities, biodiversity and fishing exploitation patterns.

\section{MATERIAL AND METHODS}

\section{Study areas}

The western Mediterranean is a subtropical, semi-enclosed area separated from the Atlantic by a sill in the Strait of Gibraltar, with a high degree of environmental stability for both temperature (12.8$13^{\circ} \mathrm{C}$ ) and salinity (38-38.6\% ) below a depth of 200 $\mathrm{m}$ (Hopkins, 1985). The two sampled basins of the western Mediterranean (Fig. 1), the Balearic (north of the Balearic Islands) and the Algerian (south of the Balearic Islands) basins are characterised by different oceanographic and geomorphological conditions (e.g. Beckers et al., 1997; Pinot et al., 2002).

The Algerian basin acts as a reservoir for water of Atlantic origin. By contrast, the Balearic basin has a large cyclonic circulation, with two permanent fronts linked to the Northern Mediterranean Current and the Balearic Current (Millot, 1999). These frontal boundary regions, reinforced by the formation of a winter water mass with minimum temperature in the water column, are particularly relevant in the general oligotrophic context of the Mediterranean Sea as biologically active locations (Estrada, 1996). Moreover, the presence of numerous submarine canyons in the Balearic basin can also influence the environmental conditions in this area. These geomorphological structures play an important role in the transport and concentration of sediment to greater depths and have been proved to be areas of high productivity (Monaco et al., 1990). Available estimations give the annual primary production in the northwestern Mediterranean as between 77 and $100 \mathrm{~g} \mathrm{C} \mathrm{m}^{-2}$ year $^{-1}$ (Minas et al., 1988), although only about $1-5 \mathrm{~g} \mathrm{C} \mathrm{m}^{-2}$ may reach the benthic ecosystems at 800 to $1000 \mathrm{~m}$ depth (Miquel et al., 1994).

The Rockall Trough and the Porcupine Seabight (Fig. 1) are temperate regions characterised by 


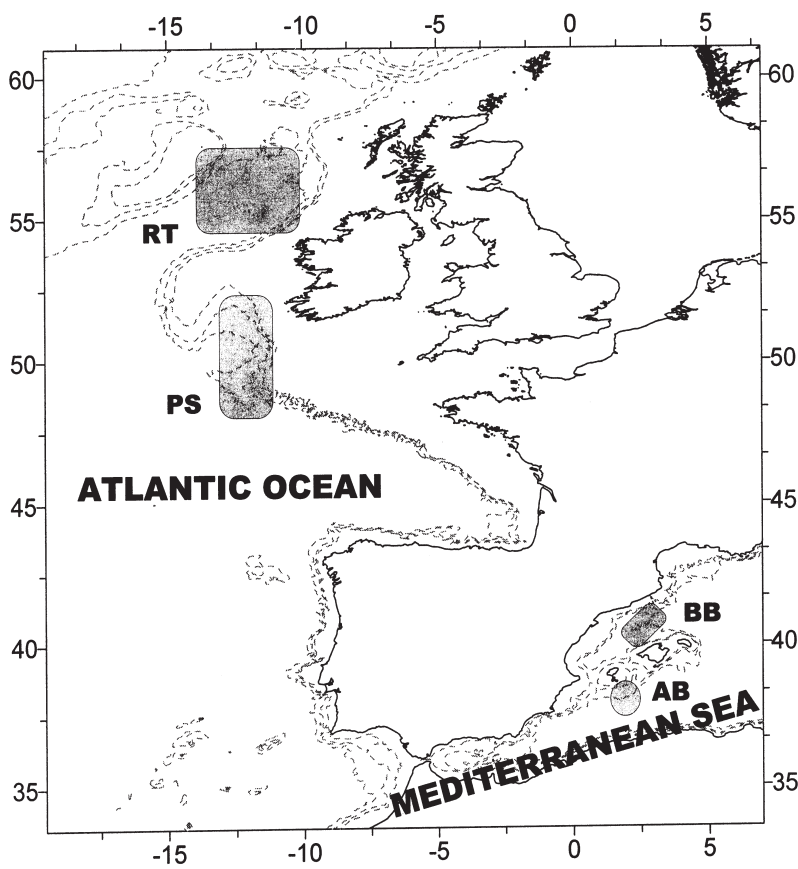

FIG. 1. - Map showing the four study areas: Balearic (BB) and Algerian $(\mathrm{AB})$ basins in the western Mediterranean; and Rockall Trough (RT) and Porcupine Seabight (PS) in the eastern North Atlantic. The 500, 1000 and $2000 \mathrm{~m}$ isobaths are shown.

marked seasonal changes in primary productivity related to increased summer temperatures $\left(11-14^{\circ} \mathrm{C}\right)$ in the upper water column and a seasonal thermocline. Below this, the environmental conditions are virtually constant throughout the year, with a gradual decrease in temperature with increasing depth, from about $10^{\circ} \mathrm{C}$ at $600 \mathrm{~m}$ to about $3.5^{\circ} \mathrm{C}$ at $2000 \mathrm{~m}$ (Ellett et al., 1986; Rice et al., 1991). There is some evidence that the two areas could constitute a marginal oceanic region in the eastern Atlantic, where greater than average production takes place compared with adjacent regions (Mauchline, 1990). Although direct measurements of annual primary production are not available, the general rate for these areas appears to be within the range 60-100 g $\mathrm{C} \mathrm{m}^{-2}$ year $^{-1}$, with a vertical flux to the deeper layers of about 12-20 $\mathrm{g} \mathrm{C} \mathrm{m}^{-2}$ (Berger et al., 1989).

\section{Sampling and data sets}

Data were derived from a series of bottom trawl surveys carried out between 1978 and 1998 by different groups of researchers, studying the distribution and ecology of deep-sea benthic and benthopelagic communities. Catch data from a total of 214 hauls were used in the analysis (Fig. 2): 60 trawls between 429 and $1862 \mathrm{~m}$ depth (Balearic basin) and 38 trawls between 402 and $1713 \mathrm{~m}$ depth (Algerian basin) in the

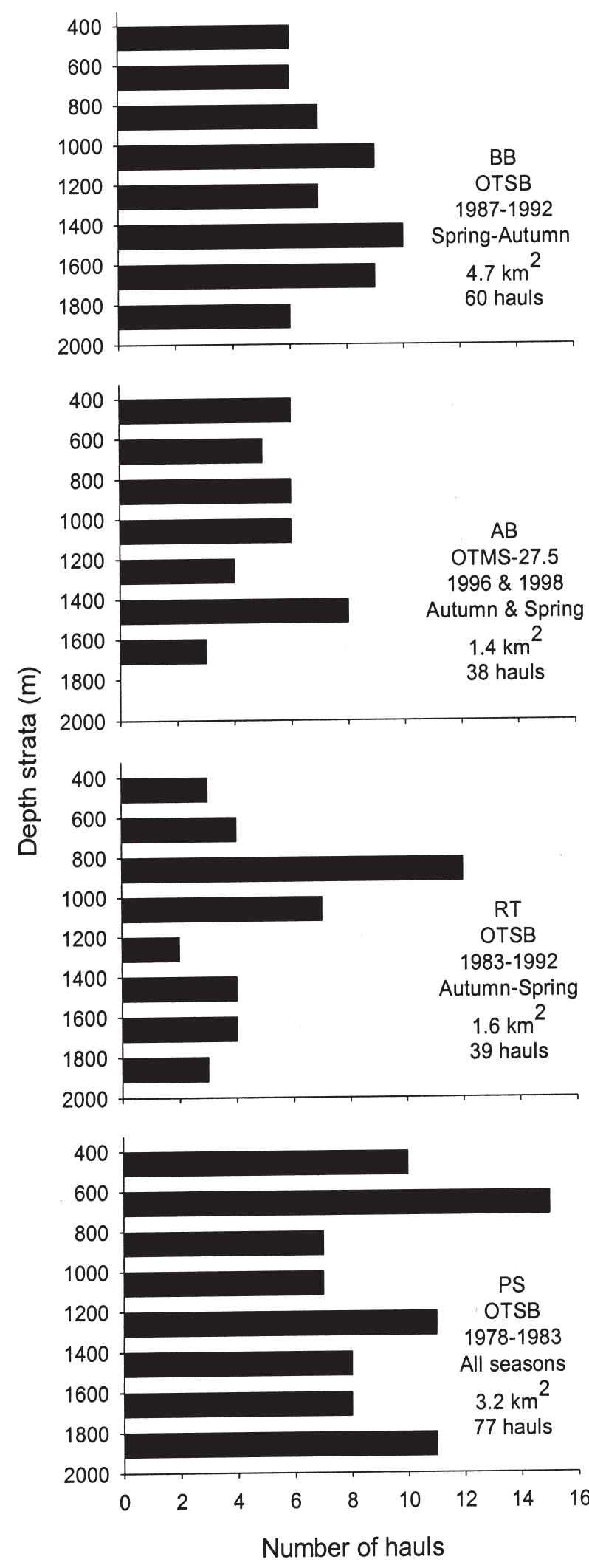

FIG. 2. - Sampling data (trawl gear used, period, area) and number of hauls (by $200 \mathrm{~m}$ depth-strata) used in this study for each area: Balearic (BB) and Algerian (AB) basins, in the western Mediterranean, and Rockall Trough (RT) and Porcupine Seabight (PS), in the eastern North Atlantic. 
western Mediterranean; and 39 trawls between 530 and $1955 \mathrm{~m}$ depth (Rockall Trough) and 77 trawls between 407 and 1993 m depth (Porcupine Seabight) in the eastern North Atlantic.

As long-term routine monitoring of fish assemblages tends to be confined to the economically more important shelf species, there are relatively few long time-series of data on deep-sea fish assemblages using standardised sampling methods. For this reason, catches from different years and seasons have been pooled in our analysis.

It has also been recognised that there are considerable differences between catches, in terms of species composition, relative abundance and length frequency, from otter bottom trawls towed on single or paired warps (e.g. Merrett et al., 1991; Gordon et al., 1996). Therefore, only samples obtained by a single warp trawl were analysed. In the Rockall Trough, Porcupine Seabight and the Balearic basin, the gear used was a standard OTSB-14 (e.g. Rucabado et al., 1991), whereas in the Algerian basin the modified semi-balloon otter trawl OTMS27.5 (Sardà et al., 1998) was used. Both gears were towed at 2.5 knots and had similar vertical openings $(1.5-2.0 \mathrm{~m})$, with their effective horizontal openings considered to be around 6.7 and $14 \mathrm{~m}$ respectively and a codend mesh size of $12 \mathrm{~mm}$.

Values were obtained for the number and weight of individuals, as well as the length frequencies of demersal fish species at each station. Depending on the morphology of the species examined, total length, head length, pre-anal length, standard length or gnathoproctal length was measured for the total catch or for random sub-samples. Biomass and abundance were standardised to a common sampled area $\left(1000 \mathrm{~m}^{2}\right)$, according to the methodology most commonly employed in studies of deep-sea fish assemblages. This calculation takes into account the greater path width of the OTMS - 27.5 trawl. This trawl was specifically designed to improve the catch rates of decapod crustaceans, but it also yielded some significantly different catch rates of some fish species (Sardà et al., 1998). Weight was calculated using available length-weight relationships obtained during these samplings.

\section{Data analysis}

For analysis, the data were grouped into the following depth intervals: $400-800 \mathrm{~m}, 800-1400 \mathrm{~m}$ and 1400-2000 m. These depth strata approximately correspond to the upper, middle and lower slopes pro- posed by Haedrich and Merrett (1988) in the North Atlantic, and to the different fish groups identified along the continental slope of the western Mediterranean (Stefanescu et al., 1993; Moranta et al., 1998).

Standardised catch data were pooled for these depth intervals, and the ecological parameters of species richness, biomass $\left(\mathrm{kg} 1000 \mathrm{~m}^{-2}\right)$ and abundance $\left(\mathrm{n} .1000 \mathrm{~m}^{-2}\right)$ were determined. For comparative purposes, the geometric mean $[\ln (x+1)]$ was preferred to the arithmetic mean for biomass and abundance, in order to minimise the negative effect of extreme values. The normality of these parameters was examined for standard skewness and kurtosis, and the homogeneity of variance was investigated using Cochran's test. The examination of the data, with unbalanced numbers of hauls per region and depth strata, indicated that the assumptions of normality and homogeneity of variances were violated. However, according to Underwood (1997), the analysis of variance may be considered robust and not greatly affected by violations of the assumptions where samples are relatively large $(n>6)$ and a more conservative significance level is adopted (in this case $p<0.01$ ). Two-factor orthogonal analysis of variance (ANOVA) was used to test differences between the mean values of the ecological parameters for both studied areas and depth strata. After ANOVA, a Bonferroni multiple range test was applied to determine which means were significantly different.

Cluster analyses using the Bray-Curtis index and the Unweighted Pair Group Method with Arithmetic Mean (UPGMA) as the aggregation algorithm was applied to calculate and visualise similarities between the taxonomic composition, both in terms of biomass and abundance of main groups, by depth strata and area. For the analysis, only the groups representing more than $0.1 \%$ of the total catch in the assemblage were considered. The Bray-Curtis index was also applied to calculate the similarity percentage between areas in terms of species composition.

Biomass by size class for each assemblage was estimated following standard methodologies, using $\log _{2}$ groupings of fish weight (g) on the $x$-axis (e.g. Macpherson and Gordoa, 1996). Correspondence analysis was used to examine the patterns of variation of assemblages in relation to different size classes. This technique has the advantage of providing a simultaneous representation of variables (assemblages) and descriptors (size classes) in a common system of orthogonal axes. 
TABLE 1. - Mean standardised biomass and abundance for each assemblage ( \pm standard error) and results of the statistical analysis (BB, Balearic basin; AB, Algerian basin; RT, Rockall Trough; PS, Porcupine Seabight; US, upper slope; MS, middle slope; LS, lower slope; SS, sum of squares; DF, degrees of freedom; F, statistic). *, indicate $\mathrm{P}<0.01$.

\begin{tabular}{|c|c|c|c|c|c|c|}
\hline & & & Medit & & & \\
\hline & Upper & $\begin{array}{l}\text { Balearic Basin } \\
\text { Middle }\end{array}$ & Lower & Upper & $\begin{array}{l}\text { Algerian Basin } \\
\text { Middle }\end{array}$ & Lower \\
\hline \multirow{4}{*}{$\begin{array}{l}\mathrm{kg} 1000 \mathrm{~m}^{-2} \\
\text { n. } 1000 \mathrm{~m}^{-2}\end{array}$} & $0.16 \pm 0.01$ & $0.42 \pm 0.05$ & $0.12 \pm 0.01$ & $0.15 \pm 0.03$ & $0.81 \pm 0.05$ & $0.44 \pm 0.06$ \\
\hline & $6.53 \pm 0.42$ & $3.52 \pm 0.32$ & $3.44 \pm 0.35$ & $3.74 \pm 0.73$ & $3.48 \pm 0.22$ & $3.74 \pm 0.42$ \\
\hline & \multicolumn{6}{|c|}{ Atlantic Ocean } \\
\hline & Upper & $\begin{array}{l}\text { Rockall Trough } \\
\text { Middle }\end{array}$ & Lower & Upper & $\begin{array}{l}\text { Porcupine Seabight } \\
\text { Middle }\end{array}$ & Lower \\
\hline $\mathrm{kg} 1000 \mathrm{~m}^{-2}$ & $4.16 \pm 1.34$ & $4.36 \pm 0.51$ & $3.02 \pm 0.81$ & $0.93 \pm 1.42$ & $1.23 \pm 0.11$ & $1.02 \pm 0.13$ \\
\hline n. $1000 \mathrm{~m}^{-2}$ & $18.22 \pm 4.61$ & $24.97 \pm 2.93$ & $12.91 \pm 3.34$ & $16.92 \pm 2.52$ & $10.15 \pm 1.10$ & $7.02 \pm 1.13$ \\
\hline
\end{tabular}

a) Statistical test for biomass $\ln (x+1)$ transformed

\begin{tabular}{lccc}
\multicolumn{2}{l}{ Analysis of variance } & & \\
& SS & DF & MS \\
Area & 34.44 & 3 & 11.48 \\
Depth & 2.22 & 2 & 1.11 \\
R x D & 0.84 & 6 & 0.14 \\
Residual & 17.14 & 202 & 0.08 \\
Total & 62.14 & 213 &
\end{tabular}

\begin{tabular}{|c|c|c|c|c|c|}
\hline $\mathrm{F}$ & $\begin{array}{l}\text { Bonferroni te } \\
\text { Area }\end{array}$ & & & & \\
\hline \multirow{9}{*}{$\begin{array}{c}135.4 * \\
13.07 * \\
1.66\end{array}$} & Group & BB (1) & $\mathrm{AB}(2)$ & RT (3) & PS (4) \\
\hline & Mean & 0.18 & 0.35 & 1.43 & 0.64 \\
\hline & Differences & ${ }^{1-2} 0.17$ & $2-31.09 *$ & ${ }^{3-4} 0.80 *$ & \\
\hline & & ${ }^{1-3} 1.26^{*}$ & ${ }^{2-4} 0.29 *$ & & \\
\hline & & ${ }^{1-4} 0.46^{*}$ & & & \\
\hline & Depth & & & & \\
\hline & Group & US (1) & MS (2) & LS (3) & \\
\hline & Mean & 0.58 & 0.80 & 0.58 & \\
\hline & Differences & $\begin{array}{c}1-2-0.22 * \\
1-3-0.00\end{array}$ & ${ }^{2-3} 0.22 *$ & & \\
\hline
\end{tabular}

b) Statistical test for abundance $\ln (x+1)$ transformed

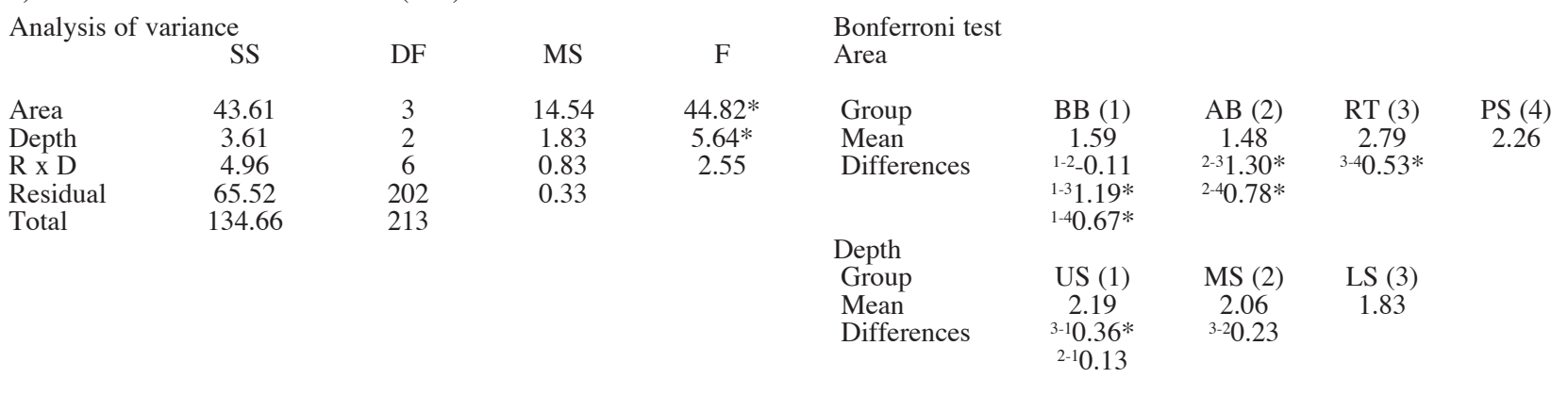

\section{RESULTS}

\section{Biomass and abundance}

The samples analysed yielded a total biomass of $11153 \mathrm{~kg}$ belonging to 140 species of 46 families (Appendix). Despite the different sampling effort in each area, large differences between the Mediterranean and the Atlantic assemblages were observed in the total catch. The 1.4 and $1.6 \mathrm{~km}^{2}$ sampled in the Algerian basin and the Rockall Trough respectively yielded a total catch of 719 and $6089 \mathrm{~kg}$ respectively. Similarly, in the Balearic basin $\left(4.7 \mathrm{~km}^{2}\right.$ sampled $)$ and the Porcupine Seabight $\left(3.2 \mathrm{~km}^{2}\right.$ sampled), the total catch was 976 and $3369 \mathrm{~kg}$ respectively.

No interactions were identified between the variables area and depth strata, and standardised biomass and abundance values were found to be signif- icantly different for both of these variables. The highest values were from the Rockall Trough and the lowest values were from the two Mediterranean areas. There was no significant difference between biomass and abundance values for the two Mediterranean areas (Table 1). There were significant differences in biomass between depth strata due to the high biomass values of middle slope assemblages, whereas for abundance the only significant difference was between the upper and lower slope.

\section{Species richness and taxonomic composition}

The number of species captured was 43 in the Balearic basin, 47 in the Algerian basin, 80 in the Rockall Trough and 104 in the Porcupine Seabight (Table 2). The percentage similarities within both the Mediterranean and Atlantic areas were much 
TABLE 2. - Total number of species (in bold) in each studied area and common species and percentage similarity (from Bray-Curtis similarity index) between the areas: Balearic basin (BB); Algerian basin (AB); Rockall Trough (RT); Porcupine Seabight (PS).

\begin{tabular}{lcccc}
\hline & \multicolumn{4}{c}{ Percentage similarity } \\
& BB & AB & RT & PS \\
\hline BB & $\mathbf{4 3}$ & 85 & 35 & 38 \\
AB & 35 & $\mathbf{4 7}$ & 34 & 35 \\
RT & 23 & 22 & $\mathbf{8 0}$ & 75 \\
PS & 27 & 26 & 69 & $\mathbf{1 0 4}$ \\
\hline
\end{tabular}

Number of common species

higher than between the Mediterranean and Atlantic assemblages. A similar trend was evident when the number of species in common between areas was examined (Table 2).

In the Mediterranean, there was no obviously predominant family over the whole depth range
(Table 3). The dominant families of the upper slope assemblages were Gadidae and Scyliorhinidae in terms of biomass and Gadidae and Macrouridae in terms of abundance. On the middle slope, Moridae and Alepocephalidae dominated in terms of biomass, while Moridae, Alepocephalidae and Macrouridae dominated in terms of abundance. On the lower slope, Alepocephalidae was the most important family in terms of biomass, whereas Chlorophthalmidae and Macrouridae dominated in terms of abundance.

By contrast, in both the Atlantic areas, the family Macrouridae was the most important in terms of biomass throughout the whole depth range surveyed (Table 3), although other important families included Gadidae and Chimaeridae on the upper slope, Moridae and Alepocephalidae on the middle slope and Synaphobranchidae on the lower slope. Synaphobranchidae and Macrouridae were the most important families in terms of abundance at all depth strata.

TABLE 3. - Percentage biomass and abundance (between brackets) composition for the most important families obtained by depth-strata in each area.

\begin{tabular}{|c|c|c|c|c|c|c|c|c|}
\hline Upper & \multicolumn{2}{|c|}{$\%$} & Middle & \multicolumn{2}{|c|}{$\%$} & Lower & \multicolumn{2}{|c|}{$\%$} \\
\hline \multicolumn{9}{|l|}{ BALEARIC BASIN } \\
\hline Gadidae & 42.3 & (46) & Moridae & 39.3 & (59) & Alepocephalidae & 36.4 & $(5)$ \\
\hline Scyliorhinidae & 22.9 & (2) & Alepocephalidae & 15.0 & (8) & Chlorophthalmidae & 23.1 & (51) \\
\hline Macrouridae & 20.5 & (24) & Macrouridae & 13.8 & (12) & Moridae & 20.7 & (11) \\
\hline Moridae & 6.0 & (5) & Gadidae & 11.6 & (2) & Squalidae & 7.9 & $(0.7)$ \\
\hline Notacanthidae & 2.5 & (4) & Hexanchidae & 6.3 & $(0.1)$ & Macrouridae & 7.7 & (24) \\
\hline Squalidae & 1.8 & (1) & Squalidae & 3.8 & $(0.3)$ & Bythytidae & 1.8 & (3) \\
\hline \multirow[t]{2}{*}{ Cynoglossidae } & 1.3 & (7) & Scyliorhinidae & 3.6 & (1) & Scyliorhinidae & 1.2 & $(0.1)$ \\
\hline & & & Lophiidae & 3.3 & $(0.1)$ & Notacanthidae & 1.1 & (5) \\
\hline \multicolumn{9}{|l|}{ ALGERIAN BASIN } \\
\hline Gadidae & 41.7 & (43) & Moridae & 35.5 & (17) & Alepocephalidae & 74.5 & (22) \\
\hline Scyliorhinidae & 28.6 & (13) & Alepocephalidae & 32.5 & (33) & Squalidae & 10.0 & (3) \\
\hline Macrouridae & 11.0 & (23) & Scyliorhinidae & 12.1 & (7) & Moridae & 6.8 & (4) \\
\hline Trachichthyidae & 6.2 & (5) & Squalidae & 5.4 & (2) & Scyliorhinidae & 3.0 & $(0.6)$ \\
\hline Squalidae & 5.8 & (3) & Gadidae & 4.7 & (5) & Chlorophthalmidae & 2.7 & (47) \\
\hline Trichiuridae & 1.0 & $(0.9)$ & Macrouridae & 4.0 & (29) & Macrouridae & 2.1 & (21) \\
\hline \multicolumn{9}{|l|}{ ROCKALL TROUGH } \\
\hline Macrouridae & 43.1 & $(22)$ & Macrouridae & 38.0 & (37) & Macrouridae & 62.7 & $(8)$ \\
\hline Chimaeridae & 18.1 & (5) & Alepocephalidae & 16.9 & (5) & Synaphobranchidae & 10.9 & (33) \\
\hline Gadidae & 13.0 & (3) & Squalidae & 11.6 & (1) & Moridae & 8.7 & (4) \\
\hline Squalidae & 7.0 & $(0.3)$ & Gadidae & 9.0 & $(0.5)$ & Chimaeridae & 4.0 & $(0.4)$ \\
\hline Moridae & 7.0 & (21) & Moridae & 6.8 & (6) & Alepocephalidae & 3.9 & (1) \\
\hline Trichiuridae & 2.2 & $(0.3)$ & Chimaeridae & 6.3 & (5) & Squalidae & 3.4 & $(0.5)$ \\
\hline \multirow[t]{2}{*}{ Synaphobranchidae } & 1.3 & $(40)$ & Synaphobranchidae & 3.9 & (39) & & & \\
\hline & & & Rajidae & 2.3 & $(0.1)$ & & & \\
\hline \multicolumn{9}{|c|}{ PORCUPINE SEABIGHT } \\
\hline Macrouridae & 19.1 & (21) & Macrouridae & 33.0 & (30) & Macrouridae & 39.3 & (24) \\
\hline Gadidae & 16.7 & (6) & Moridae & 29.0 & (13) & Synaphobranchidae & 20.6 & (59) \\
\hline Moridae & 14.9 & (18) & Trachichthyidae & 9.8 & (2) & Alepocephalidae & 8.9 & (4) \\
\hline Lophiidae & 13.4 & $(0.1)$ & Alepocephalidae & 8.8 & (2) & Moridae & 7.9 & (4) \\
\hline Squalidae & 9.7 & $(0.3)$ & Squalidae & 4.7 & $(0.1)$ & Trachichthyidae & 5.7 & (2) \\
\hline Trachichthyidae & 7.2 & (2) & Rajidae & 4.1 & $(0.1)$ & Squalidae & 5.4 & $(0.2)$ \\
\hline Chimaeridae & 6.1 & $(0.6)$ & Synaphobranchidae & 3.1 & (47) & Bythytidae & 2.5 & $(0.2)$ \\
\hline Scorpaenidae & 3.5 & $(0.7)$ & Scorpaenidae & 2.3 & $(0.3)$ & Chimaeridae & 2.4 & $(0.4)$ \\
\hline Synaphobranchidae & 2.8 & (46) & Chimaeridae & 1.1 & $(0.6)$ & Notacanthidae & 1.4 & (4) \\
\hline Alepocephalidae & 1.7 & $(0.5)$ & Gadidae & 1.1 & $(0.2)$ & Ophidiidae & 1.3 & $(0.3)$ \\
\hline Notacanthidae & 1.1 & $(1.7)$ & & & & & & \\
\hline
\end{tabular}


BIOMASS

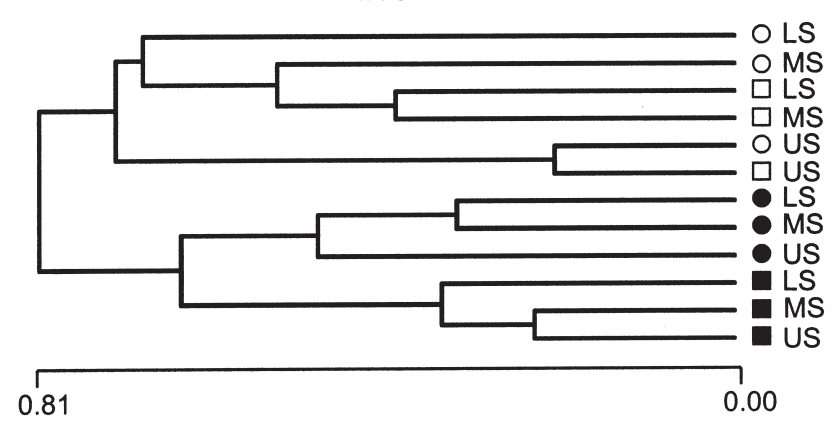

NUMBER

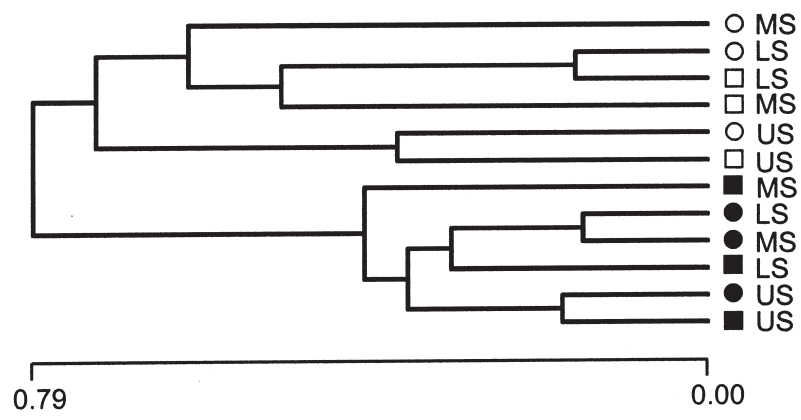

FIG. 3. - Similarity dendrograms of catch composition of total assemblages by area $(\bigcirc$, Balearic basin; $\square$, Algerian basin; $\square$, Rockall Trough; O, Porcupine Seabight) and depth-strata (US, Upper slope; MS, Middle slope; LS, Lower slope), in terms of standardised biomass $\left(\mathrm{kg} 1000 \mathrm{~m}^{-2}\right)$ and abundance $\left(\mathrm{n} .1000 \mathrm{~m}^{-2}\right)$, for the main taxonomic groups in each assemblage (see Table 3 ).

The dendrograms derived from the standardised values of biomass and abundance for taxonomic groups showed clear differentiation, in the first cluster, between Mediterranean and Atlantic assemblages (Fig. 3). The second cluster in the Mediterranean assemblage separated the upper from the middle and lower slope, both in terms of biomass and abundance, while in the Atlantic this bathymetric segregation was not so clear and the second dichotomy separated the Rockall Trough and the Porcupine Seabight assemblages in terms of biomass, but not abundance.

\section{Size-related structure}

The biomass spectra for the whole depth range surveyed in each area (Fig. 4) showed a clear gradient from the Balearic basin, in which $88 \%$ of the biomass was found between size classes 3 and 9 with a mode at 7 , to the Rockall Trough, in which $80 \%$ of the biomass was situated between size classes 8 and 13, with a mode at 10. The Algerian basin and the Porcupine Seabight had intermediate modes,
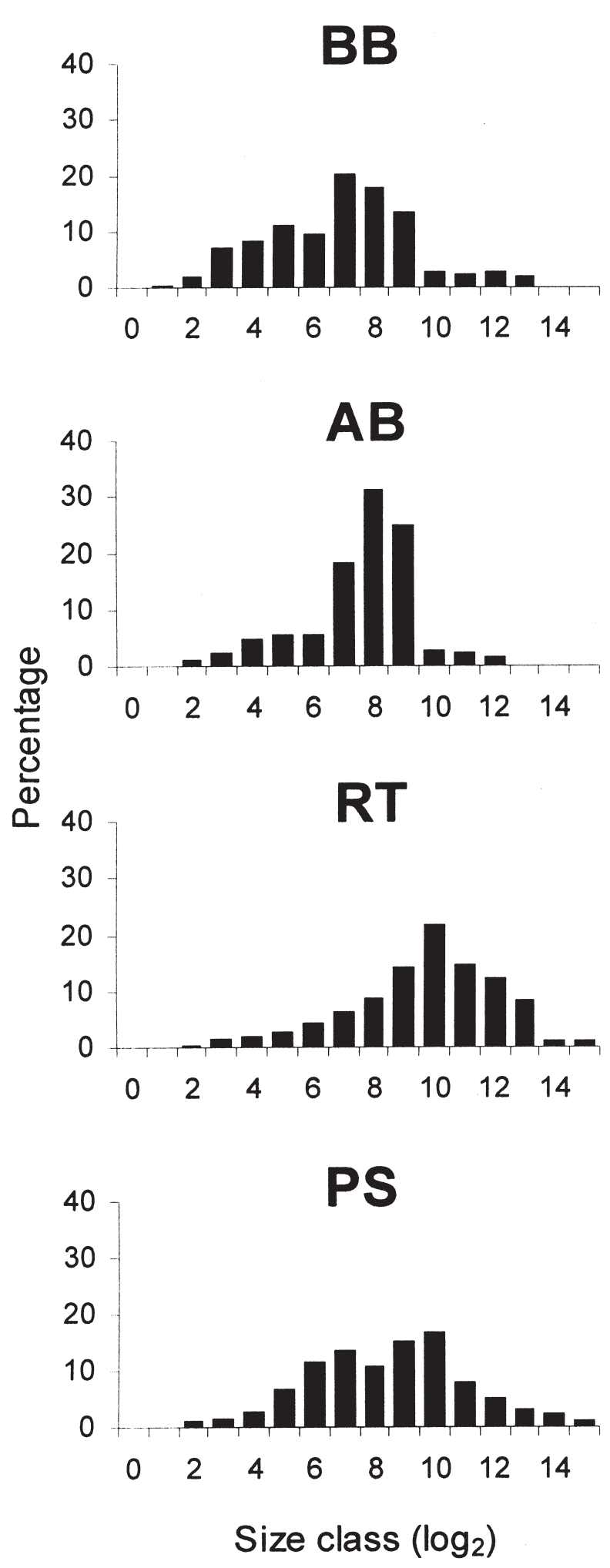

FIG. 4. - Percentage of total biomass by size-class in the four studied areas: Balearic (BB) and Algerian (AB) basins, in the western Mediterranean; and Rockall Trough (RT) and Porcupine Seabight (PS), in the eastern North Atlantic.

with more than $85 \%$ of the biomass from size classes 4-9 and 5-12 respectively. 

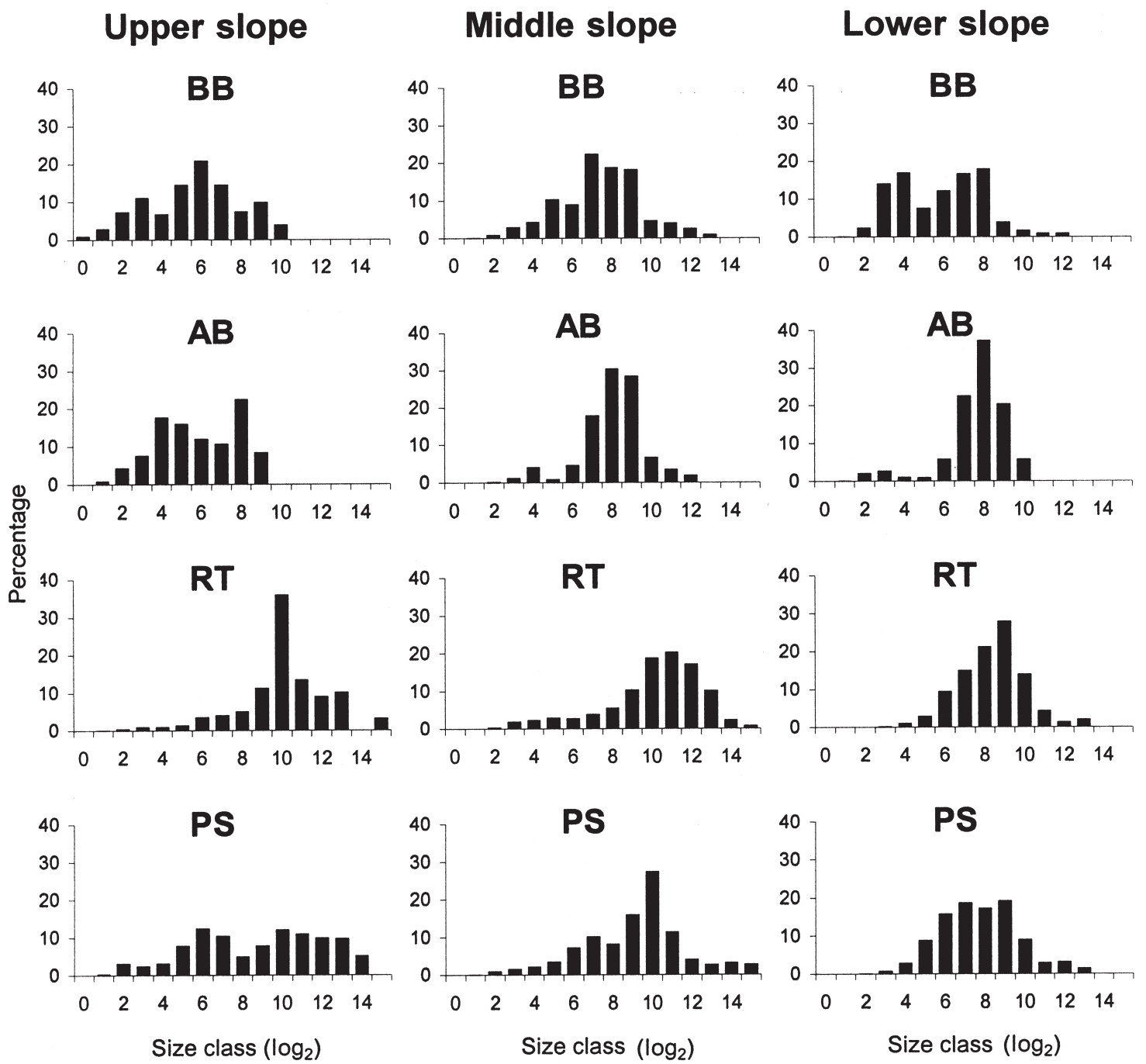

FIG. 5. - Percentage of total biomass by size-class and depth-strata in the four studied areas: Balearic (BB) and Algerian (AB) basins, in the western Mediterranean; and Rockall Trough (RT) and Porcupine Seabight (PS), in the eastern North Atlantic.

Similar trends were observed for the selected depth strata (Fig. 5), with greater differences on the upper slope, where a higher percentage of the biomass was comprised of size classes $\leq 6$ in the Mediterranean assemblages and of size classes $\geq 5$ in the Atlantic assemblages. The only exception was found on the lower slope, where the biomass spectrum from the Algerian basin was similar to those found in the Atlantic assemblages. The correspondence analysis applied to biomass spectra by depth strata showed that data were arranged in a parabolic form (Fig. 6), which signified a clear gradient. The first axis (F1) explained $58 \%$ of the variability and discriminated between the Mediterranean assemblages, in which biomass was mainly distributed in small and middle size classes, and the Atlantic assemblages, which were more related to larger size classes (10-13).

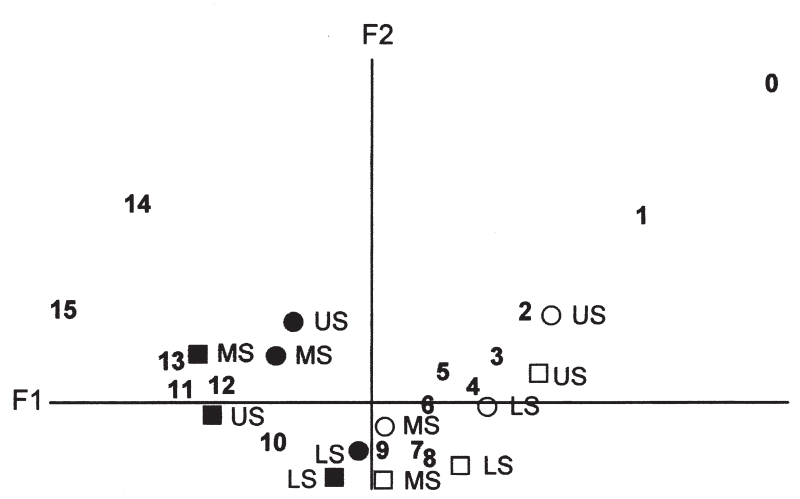

FIG. 6. - Correspondence analysis of biomass spectra of total assemblages by area $(\bigcirc$, Balearic basin; $\square$, Algerian basin; $\mathbf{\square}$, Rockall Trough; O, Porcupine Seabight) and depth-strata (US, Upper slope; MS, Middle slope; LS, Lower slope). Numbers correspond to the size classes of Figure 5. 
TABLE 4. - Average (arithmetic Mean), minimum (Min) and maximum (Max) length (TL, total length; GL, gnathoproctal length; HL, head length) of the species appearing in the four assemblages (BB, Balearic basin; AB, Algerian basin; RT, Rockall Trough; PS, Porcupine Seabight), in which more than ten specimens could be measured (n).

\begin{tabular}{|c|c|c|c|c|c|c|c|c|c|}
\hline Area & Mean & Min & $\operatorname{Max}$ & $\mathrm{n}$ & Area & Mean & Min & $\operatorname{Max}$ & $\mathrm{n}$ \\
\hline \multicolumn{5}{|c|}{ Centroscymnus coelolepis $\mathrm{cm} \mathrm{TL}$} & \multicolumn{5}{|c|}{ Coelorhynchus coelorhynchus $\mathrm{cm} \mathrm{HL}$} \\
\hline BB & 27.4 & 17 & 61 & 46 & $\mathrm{BB}$ & 4.5 & 1.6 & 7.9 & 75 \\
\hline $\mathrm{AB}$ & 36.9 & 20 & 91 & 39 & $\mathrm{AB}$ & 3.6 & 3.1 & 4.3 & 27 \\
\hline RT & 96.4 & 84 & 112 & 54 & RT & 6.6 & 2.9 & 9.5 & 119 \\
\hline PS & 92.2 & 78 & 106 & 13 & PS & 5.8 & 1.7 & 8.5 & 58 \\
\hline
\end{tabular}

Notacanthus bonapartei $\mathrm{cm} \mathrm{GL}$

$\begin{array}{lcccc}\text { BB } & 4.7 & 3.9 & 9.5 & 88 \\ \text { AB } & 4.2 & 2.5 & 10.0 & 25 \\ \text { RT } & 8.9 & 4.0 & 22.0 & 649 \\ \text { PS } & 10.0 & 3.0 & 27.0 & 346\end{array}$

Nezumia aequalis $\mathrm{cm} \mathrm{HL}$

Polyacanthonotus rissoanus cm GL

$\begin{array}{lcccc}\text { BB } & 5.1 & 3.5 & 6.0 & 71 \\ \text { AB } & 5.5 & 3.5 & 6.0 & 28 \\ \text { RT } & 9.1 & 4.0 & 20.0 & 275 \\ \text { PS } & 10.5 & 4.0 & 19.0 & 528\end{array}$

Phycis blennoides $\mathrm{cm}$ TL

$\begin{array}{lcccc}\text { BB } & 14.5 & 6.0 & 62.0 & 1282 \\ \text { AB } & 16.7 & 6.0 & 53.0 & 54 \\ \text { RT } & 34.8 & 10.1 & 68.2 & 13 \\ \text { PS } & 27.4 & 6.8 & 71.6 & 28\end{array}$

Mora moro cm TL

\begin{tabular}{lcccccccc} 
BB & 31.5 & 5.0 & 50.0 & 329 & BB & 12.5 & 3.0 & 32.0 \\
AB & 34.8 & 11.0 & 53.0 & 324 & AB & 2.0 & 29.0 & 562 \\
RT & 39.9 & 17.2 & 72.7 & 83 & RT & 17.1 & 11.4 \\
PS & 44.2 & 6.1 & 72.7 & 193 & PS & 20.6 & 6.6 \\
\hline
\end{tabular}

Clear size differences were also observed, at a species level, by comparing the length of ten species captured in significant numbers within the four areas (Table 4). In all cases, both maximum (with the only exception of Helicolenus dactylopterus) and mean lengths were higher in the Atlantic than in the Mediterranean. By contrast, minimum lengths were more similar, with the only exceptions of Centroscymnus coelolepis and Helicolenus dactylopterus, where the minimum size in the Atlantic was at least double that found in the Mediterranean.

\section{DISCUSSION}

The standardised comparisons of this study confirm the clear differences between the deep-sea demersal fish fauna of the Mediterranean and the Atlantic, which were already suggested four decades ago by Tortonese (1960) and more recently shown, at a species level, by Stefanescu et al. (1992) and D’Onghia et al. (1998).

\section{Biomass and abundance}

The biomass and abundance indices were lower for the Mediterranean assemblages than for the Atlantic. The factors that cause these differences are likely to be complex. Although the influence of surface productivity on demersal megafauna is poorly understood, pelagic production and its arrival, as phytodetritus, on the sea floor has been reported as one of the most important sources of organic matter for the northwestern Mediterranean (Miquel et al., 1994) and eastern North Atlantic (Rice et al., 1986) deep-sea ecosystems. Although similar ranges of surface productivity have been estimated in these areas, the availability of organic matter at the seabed in the Atlantic, which has been estimated as an order of magnitude higher than in the Mediterranean (around 20\% and 2-5\%, respectively; see Material and Methods), could contribute to the differences in density of fish fauna between the two areas. The higher temperature below $200 \mathrm{~m}$ in the Mediterranean could contribute to a faster decompo- 
sition of the organic matter during its transport through the water column before its arrival to the sea floor as food source.

Studies on the diets of deep-water fishes in the Rockall Trough (Mauchline and Gordon, 1991 and references cited therein) have shown the dominance of meso, bathy and benthopelagic prey. Therefore, the enhanced demersal biomass down to about 1000-1500 $m$ depth most probably results from the efficient transfer of surface production, via overlapping food chains and vertical migration of prey. Conversely, in the western Mediterranean, it has been suggested that this energy transfer mechanism only reaches about 8001000 m depth (Cartes, 1998).

The higher values of fish abundance obtained from the upper slope of the Balearic basin could be related to the presence of submarine canyons, which were absent in the Algerian basin. It has been shown that these geomorphological structures are a means of transporting sediments rich in organic matter from the continental shelf, and that they also create a focus for diel migrations of plankton from upper levels (Macquart-Moulin and Patriti, 1993). These canyons can act as recruiting grounds for both fish (Stefanescu et al., 1994) and crustaceans (Cartes et al., 1994). Similarly, the Rockall Trough has a gentle slope, with no canyons, and except at around $400-500 \mathrm{~m}$, is composed of soft mud with an increasing biogenic content with depth (Mitchell et al., 1997), while the Porcupine Seabight is bisected by canyons (Rice et al., 1991) that separate a northern and a southern trawlable area. The northern area is comprised of very soft sediments, especially at mid-slope depths, and dense aggregations of the sponge, Pheronema carpenteri (Rice and Thurston, 1990). Multivariate analysis separated the catches of the larger paired warp trawl between these two areas, but the OTSB catches were not separable (Gordon et al., 1996).

The biomass indices showed some similar bathymetric trends between all four areas, with a maximum on the middle slope, while abundance indices were more variable. The peak of biomass in both the Balearic and Algerian basins occurs at between 1000 and 1200 m depth (Stefanescu et al., 1993; Moranta et al., 1998 respectively), which results both from some medium and large-sized species reaching their greatest abundance at these depths (e.g. Alepocephalus rostratus, Morales-Nin et al., 1996) and from other species reaching their greatest biomass due to a bigger deeper trend (e.g. Trachyrincus scabrus and Phycis blennoides; Massutí et al., 1995 and 1996 respectively). The isobath of $1200 \mathrm{~m}$ is considered to be about the lower limit of the mesopelagic fauna and the reduction of this trophic resource probably accounts for the decline in biomass on the Mediterranean lower slope (Stefanescu et al., 1993). In the Rockall Trough, biomass had maximum values at mid-slope depths. This peak, which was evident using several different trawls (Gordon, 1986), is most probably related to the depth range of greatest potential vertical and horizontal impingement of epi- and mesopelagic fauna on the slope (Mauchline and Gordon, 1991). Similar results were obtained using several trawl types in the Porcupine Seabight (Merrett et al., 1991).

\section{Species richness and taxonomic composition}

Atlantic assemblages are composed of a larger number of species than those of the Mediterranean, which has been widely described as being less diverse than the Atlantic for some groups (Bouchet and Taviani, 1992). The more constant physical environment and the recent origin of the deep-sea fauna of the Mediterranean (Pérès, 1985) probably accounts for the fewer number of species. In the Atlantic, the Porcupine Seabight has a greater number of species than the Rockall Trough. The Rockall Trough is a semi-enclosed area, which is only open to the deeper water in the south. The relatively shallow sills to the west and north create a physical barrier to the movement of deep-water fish species. The markedly different hydrographic differences between the Rockall Trough and the Norwegian Sea have resulted in almost no similarity in the deep-water fish fauna between these areas (Bergstad et al., 1999). On the other hand, there are many species in common between the Rockall Trough and the Porcupine Seabight (Gordon et al., 1996). The Porcupine Seabight also has affinities with the northwest African slope, where there is a high diversity in some families (e.g. Alepocephalidae; Merrett and Domanski, 1985), and the presence of some species has been attributed to the presence of a Lusitanian (Mediterranean) influence in the area (e.g. Hoplostethus mediterraneus; Ratz, 1984). Mediterranean water is clearly identified in the Porcupine Seabight (Rice et al., 1991), but previous reports of traces of Mediterranean water in the Rockall Trough are now being questioned (New and Smythe-Wright, 2001). In addition to these biogeographic factors, the proximity of the slope of the Porcupine Seabight to abyssal depths compared to that of the Rockall Trough could also increase the 
species number in this area, through the capture of juveniles of abyssal-living species (e.g. Coryphaenoides leptolepis and Coryphaenoides carapinus).

There are some very clear differences in the families that dominate the biomass between the Mediterranean and the Atlantic. In the Mediterranean, a different family dominates each of the bathymetric zones: Gadidae on the upper slope, Moridae on the middle slope and Alepocephalidae on the lower slope. By contrast, in the Atlantic the family Macrouridae was dominant in each bathymetric zone. The different food availability and the partitioning of the main trophic resources within these ecosystems (among mostly fish in the Atlantic and between decapods and fish in the Mediterranean) may explain some of these differences. The dominant Macrouridae in the Atlantic (Coryphaenoides rupestris, Nezumia aequalis and Coryphaenoides guentheri) feed on small macroplankton (Mauchline and Gordon, 1984). On the upper and middle slope of the Mediterranean, this trophic resource may also be used by benthopelagic decapods, which in turn could provide food for the dominant fish and/or for their prey [Gadidae, Scyliorhinidae, Macrouridae and Moridae (Macpherson, 1978, 1980; Carrasón et al., 1997, Carrasón and Matallanas, 2002)]. The Alepocephalidae are dominant on the Mediterranean lower slope. They have a conservative feeding strategy (float and wait), typical of oligotrophic conditions (Haedrich, 1996), which seems to confer an advantage over the more active foragers (Macrouridae and Synaphobranchidae) that predominate on the Atlantic lower slope.

\section{Size-related structure}

Biomass spectra show the distribution of overall biomass within the assemblages and can indicate the relative importance of different fish sizes with respect to energy flow (Haedrich and Merrett, 1992). According to these authors, flat spectra correspond to areas where food supply is rather uniform over the entire year, whereas spiky spectra characterise areas where production is pulsed. The observed patterns in the Mediterranean and the Atlantic both show a predominantly modal biomass spectrum, suggesting that their most important energy source might be seasonal.

The biomass spectra show clear differences between Mediterranean and Atlantic assemblages where, respectively, small-middle and middle-large size classes predominate. Where the same species occurs in both the Mediterranean and the Atlantic, those in the Mediterranean tend to attain a smaller adult size. As a consequence, these fish will have smaller mouths and will therefore utilise a different component of the available food resource. Competition for this food resource by the invertebrate fauna, notably the decapod crustaceans, may be an important factor in determining the overall biomass spectra (Cartes et al., 2001).

The differences in biomass spectra between Mediterranean and Atlantic assemblages depend on the depth strata. Differences were greatest on the upper slope and these are most likely related to the fishing exploitation of this bathymetric range in both Mediterranean areas, where important bottom trawl fisheries targeting decapod crustaceans have been carried out since the 1960s (Bas et al., 1985). Fishing exploitation has been demonstrated as an important factor affecting distribution of biomass within benthic fish assemblages (Macpherson and Gordoa, 1996). On the unexploited lower slope, biomass spectra were similar in the Atlantic assemblages. However, some differences could be observed in the Mediterranean, where the distribution was skewed to small-sized classes compared to the Atlantic. In the Balearic basin, there were two evident modes at small and middle-size classes, while in the Algerian basin there was a main mode at the middle-size class. Differences between the deep-sea fauna of these two western Mediterranean basins have been reported previously, not only in fish fauna (Moranta et al., 1998), but also in bathyal decapod crustaceans (Maynou and Cartes, 2000). These differences have been attributed to the fact that trophic webs in the Algerian basin depend more directly on food of planktonic origin, while in the Balearic basin, where there are important submarine canyons, benthic prey enhances food availability and allows a broader trophic spectrum. Thus, the greater percentage of biomass on the lower slope of the Algerian basin corresponds to the middle-sized species Alepocephalus rostratus (almost 75\%), whose diet is based on gelatinous macroplankton (Carrasón and Matallanas, 1998), while in the Balearic basin its importance decreases (representing 36\%) and other small-sized species such as Bathypterois mediterraneus and Lepidion lepidion, which prey upon benthopelagic crustaceans (Carrasón and Matallanas, 2001) and benthic decapods (Carrasón et al., 1997) respectively, also represent an important fraction of the biomass (23 
and $21 \%$ respectively). The greatest similarities between Mediterranean and Atlantic deep-sea fish assemblages were found on the middle slope. This might be due to the similar trophic webs present in this bathymetric range, in which a great proportion of the biomass ( $>60 \%$ ) corresponds to the macronekton foragers and/or epibenthos predators (Macrouridae and Moridae) and to the macroplanktonivores (Alepocephalidae).

The differences in the biomass structure between Mediterranean and Atlantic assemblages were also evident at a species level, when both mean and maximum lengths of species caught in all surveyed areas were compared. The small size of Mediterranean deep-sea fishes has already been discussed by Tortonese (1960) and more recently by Stefanescu $e t$ al. (1992). According to these authors, it is evident that this phenomenon is very complicated and is undoubtedly the result of a combination of factors of disparate origin (e.g. latitudinal gradients on fish size, ecological factors affecting body size). More limited resources and a high temperature in the Mediterranean $\left(\sim 13^{\circ} \mathrm{C}\right.$ compared to 10 to $4^{\circ} \mathrm{C}$ in the eastern Atlantic areas) could also be assumed to play an important part.

In summary, the differences found in demersal deep-sea fish assemblages between the Mediterranean and the Atlantic reinforces not only the general view of the Mediterranean deep-sea as an oligotrophic ecosystem (e.g. Bouchet and Taviani, 1992), but also the view that there are distinct differences in the size-related structure of the fish populations. The primary cause of the differences in size structure is probably a result of adaptations at both the species and ecosystem level to different trophic relationships between the two areas. The historical evolution of the Mediterranean basin, its geomorphology and markedly different environmental conditions and fishing pattern must also contribute to the differences.

\section{ACKNOWLEDGEMENTS}

The authors wish to thank to all the participants in the sampling surveys, and also the Institutions who funded the projects that provided all the data and information included in the paper. Support for the analysis of the Atlantic data was obtained from the following European Commission projects: DGXIV Study Contract (92-10) "Biological parameters of deep-water fish species", MAST2-
CT920033 and FAIR CT-95-655 "Developing deepwater fisheries: data for their assessment and for understanding their interaction with and impact on a fragile environment". This latter project also supported the studies in the Algerian basin, while those in the Balearic basin were funded by the Spanish research programs BATIMAR (PAC86-008/ID821) and ZONAP (PB90-0166). The analysis of the data and the preparation of the paper was funded by a Spanish Government Studies License and a bursary from the Scottish Association for Marine Science.

\section{REFERENCES}

Allain, V. - 2001. Reproductive strategies of three deep-water benthopelagic fishes from the northeast Atlantic Ocean. Fish. Res., 51: $165-176$

Bas, C., E. Macpherson and F. Sardà. - 1985. Fishes and Fishermen. The Exploitable Trophic Levels. In: R. Margalef (ed.), Western Mediterranean, pp. 296-316. Pergamon Press.

Beckers, J.M., P. Brasseur and J.C.J. Nihoul. - 1997. Circulation of the western Mediterranean: from global to regional scales. Deep-Sea Res., 44: 531-549.

Berger, W.H. - 1989. Appendix. Global maps of ocean productivity. In: W.H. Berger, V.S. Smetacek and G. Wefer (eds.), Productivity of the ocean: present and past, pp. 429-455. Wiley and Sons, Chichester.

Bergmann, U. - 1987. Models of the slope of, and biomass flow up, the biomass size spectrum. Can. J. Fish. Aquat. Sci., 44(Suppl. 2): $136-140$.

Bergstad, O.A., O. Bjelland and J.D.M. Gordon. - 1999. Fish communities on the slope of the eastern Norwegian Sea. Sarsia, 84: 67-78.

Bouchet, P. and M. Taviani. - 1992. The Mediterranean deep-sea fauna: pseudopopulations of Atlantic species? Deep-Sea Res., 39: $169-184$

Carrasón, M. and J. Matallanas. - 1998. Feeding habits of Alepocephalus rostratus (Pisces: Alepocephalidae) in the western Mediterranean Sea. J. Mar. Biol. Ass. UK, 78: 1295-1306.

Carrasón, M. and J. Matallanas. - 2001. Feeding ecology of the Mediterranean spiderfish Bathypterois mediterraneus (Pisces: Chlorophtalmidae) on the western Mediterranean slope. Fish. Bull., 99: 266-274.

Carrasón, M. and J. Matallanas. - 2002. Diets of deep-sea macrourid fish in the western Mediterranean slope. Mar. Ecol. Prog. Ser., 234: 215-228.

Carrasón, M., J. Matallanas and M. Casadevall. - 1997. Feeding strategies of deep-water morids on the western Mediterranean slope. Deep-Sea Res., 44: 1685-1699.

Cartes, J.E. - 1998 . Dynamics of the bathyal Benthic Boundary Layer in the north-western Mediterranean: depth and temporal variations and their possible connections within deep-sea trophic webs. Prog. Oceanogr., 41: 111-139.

Cartes, J.E., J.B. Company and F. Maynou. - 1994. Deep-water decapod crustacean communities in the Northwestern Mediterranean: influence of submarine canyons and season. Mar. Biol., 120: 221-229.

Cartes, J.E., F. Maynou, B. Morales-Nin, E. Massutí and J. Moranta. - 2001. Trophic structure of a bathyal benthopelagic boundary layer community south of the Balearic Islands (southwestern Mediterranean). Mar. Ecol. Prog. Ser., 215: 23-35.

Coggan, R.A., J.D.M. Gordon and N.R. Merrett. - 1998. Abundance, distribution, reproduction and diet of notacanthid fishes from the north-east Atlantic. J. Fish Biol., 52: 1038-1057.

D’Onghia, G., A. Tursi, C.A. Marano and M. Basanisi. - 1998. Life history traits of Hoplostethus mediterraneus (Pisces: Beryciformes) from the north-western Ionian sea (Mediterranean Sea). J. Mar. Biol. Ass. UK, 78: 321-339.

Ellett, D.J., A. Edwards and R. Bowers. - 1986. The hydrography of the Rockall Channel-an overview. Proc. Roy. Soc. Edinb., 
88B: $61-81$.

Estrada, M. - 1996. Primary production in the northwestern Mediterranean. Sci. Mar., 60(Suppl. 2): 55-64.

Gordon, J.D.M. - 1986. The fish populations of the Rockall Trough. Proc. Roy. Soc. Edinb., 88B: 191-204.

Gordon, J.D.M. and J.A.R. Duncan. - 1985. The biology of fish of the Family Moridae in the deep-water of the Rockall Trough. $J$. Mar. Biol. Ass. UK, 65: 475-485.

Gordon, J.D.M., N.R. Merrett, O.A. Bergstad and S.C. Swan. 1996. A comparison of the deep-water demersal fish assemblages of the Rockall Trough and Porcupine Seabight, eastern North Atlantic: continental slope to rise. J. Fish Biol., 49(Suppl. A): 217-238.

Haedrich, R.L. - 1996. Deep-water fishes: evolution and adaptation in the earth's largest living spaces. J. Fish Biol., 49 (Suppl. A): 40-53.

Haedrich, R.L. and N.R. Merrett. - 1988. Summary atlas of deepliving demersal fishes in the North Atlantic Basin. J. Nat. Hist., 22: 1325-1362.

Haedrich, R.L. and N.R. Merrett. - 1992. Production/biomass ratios, size frequencies, and biomass spectra in deep-sea demersal fishes. In: G.T. Rowe and V. Pariente (eds.), Deep-Sea food chains and the global carbon cycle, pp. 157-182. Kluwer Academic Publishers, Netherlands.

Hopkins. T.S. - 1985. Physics of the Sea. In: R. Margalef (ed.), Western Mediterranean, pp. 100-125. Pergamon Press.

Koslow, J.A. - 1993. Community structure in North Atlantic deepsea fishes. Prog. Oceanogr., 31: 321-338.

Macpherson, E. - 1978. Régimen alimentario de Phycis blennoides (Brünnich) y Antonogadus megalokynodon (Kolombatovic) (Pisces: Gadidae) en el Mediterráneo occidental. Inv. Pesq., 42: 455-466.

Macpherson, E. - 1980. Régime alimentaire de Galeus melastomus Rafinesque, 1810 Etmopterus spinax (L., 1758) et Scymnorhinus licha (Bonaterre, 1788) en Méditerranée occidentale. Vie Milieu, 30: 139-148

Macpherson, E. and A. Gordoa. - 1996. Biomass spectra in benthic fish assemblages in the Benguela System. Mar. Ecol. Prog. Ser., 138: 27-32

Macquart-Moulin, C. and G. Patriti - 1993. Submarine canyons and offshore advection of neritic plankton. Oceanol. Acta, 16: 179189.

Massutí, E., B. Morales-Nin and D. Lloris. - 1996. Bathymetric distribution and recruitment patterns of Phycis blennoides (Pisces: Gadidae) from the slope of the northwestern Mediterranean. Sci. Mar., 60: 481-488

Massutí, E., B. Morales-Nin and C. Stefanescu. - 1995. Distribution and biology of five grenadier fish (Pisces: Macrouridae) from the upper and middle slope of the northwestern Mediterranean. Deep-Sea Res., 42: 307-330.

Mauchline, J. - 1990. Aspects of production in a marginal oceanic region, the Rockall Trough, northeastern Atlantic Ocean. Rev. Aquat. Sci., 2: 167-183.

Mauchline, J. and J.D.M. Gordon. - 1984. Diets and bathymetric distribution of the macrourid fish of the Rockall Trough, northeastern Atlantic Ocean. Mar. Biol., 81: 107-121.

Mauchline, J. and J.D.M. Gordon. - 1991. Oceanic pelagic prey of benthopelagic fish in the benthic boundary layer of a marginal oceanic region. Mar. Ecol. Prog. Ser., 74: 109-115.

Maynou, F. and J.E. Cartes. - 2000. Community structure of bathyal decapod crustaceans off south-west Balearic Islands (western Mediterranean): seasonality and regional patterns in zonation. J. Mar. Biol. Ass. UK, 80: 789-798.

Merrett, N.R. and P.A. Domanski. - 1985. Observations on the ecology of deep-sea bottom-living fishes collected off northwest Africa: The Moroccan slope $\left(27^{\circ}-34^{\circ} \mathrm{N}\right)$, with special reference to Synaphobranchus kaupi. Biol. Oceanogr., 3: 349-399.

Merrett, N.R., J.D.M. Gordon, M. Stehmann and R.L. Haedrich. 1991. Deep demersal fish assemblage structure in the Porcupine Seabight (eastern North Atlantic): slope sampling by three different trawls compared. J. Mar. Biol. Ass. UK, 71: 329-358.

Millot, C. - 1999. Circulation in the Western Mediterranean Sea. J. Mar. Syst., 20: 423-442.

Minas, J. H., M. Minas, B. Coste, J. Gostan, P. Nival and M. C.
Bonin. - 1988. Production base et de recyclage; une revue de la problématique en Méditerranée nord-occidentale. Oceanol. Acta, Special Issue 9: 155-162.

Miquel, J.C., S.W. Fowler, J. La Rosa and P. Buat-Menard. 1994. Dynamics of the downward flux of particles and carbon in the open northwestern Mediterranean Sea. Deep-Sea Res., 41: 243-261.

Mitchell, L., S.M. Harvey, J.G. Gage and A.E. Fallick. - 1997. Organic carbon dynamics in shelf edge sediments off the Hebrides: a seasonal perspective. Int. Rev. Gesamten. Hydrobiol., 82: 425-435.

Monaco, A., P. Biscaye, J. Soyer, R. Pocklington and S. Heussner. - 1990. Particle fluxes and ecosystem response on a continental margin: the 1985-1988 Mediterranean ECOMARGE experiment. Cont. Shelf Res., 10: 809-839.

Morales-Nin, B., E. Massutí and C. Stefanescu. - 1996. Distribution and biology of Alepocephalus rostratus from the Mediterranean Sea. J. Fish Biol., 48: 1097-1112.

Moranta, J., C. Stefanescu, E. Massutí, B. Morales-Nin and D. Lloris. - 1998. Fish community structure and depth-related trends on the continental slope of the Balearic Islands (Algerian basin, western Mediterranean). Mar. Ecol. Prog. Ser., 171: 247-259.

New, A.L. and D. Smythe-Wright. - 2001. Aspects of the circulation in the Rockall Trough. Cont. Shelf Res., 21: 777-810.

Pérès, J.M. - 1985. History of the Mediterranean biota and the colonization of the depths. In: R. Margalef (ed.), Western Mediterranean, pp. 198-232. Pergamon Press, Oxford.

Platt, T. - 1985. Structure of the marine ecosystem: its allometric basis. Can. J. Fish. Aquat. Sci., 213: 55-64.

Pinot, J.-M., J.L. López-Jurado and M. Riera. - 2002. The Canales experiment (1996-1998). Interannual, seasonal, and mesoscale variability of the circulation in the Balearic Channels. Prog. Oceanogr., 55: 335-370.

Ratz, H.J. - 1984. Qualitative und quantitative Untersuchungen der Ichthyozönose in der archibenthischen Zone des Rockall Grabens und umleigender Bänke (Westbritische Gewässer). Mitt. Inst. Seefisch, 34: 152 pp.

Rice, A.L. and M.H. Thurston. - 1990. Dense aggregations of a hexactinellid sponge, Pheronema carpenteri, in the Porcupine Seabight (northeast Atlantic Ocean), and possible causes. Prog. Oceanogr., 24: 179-196.

Rice, A.L., D.S.M. Billett, J. Fry, A.W.G. John, R.S. Lampitt, R.F.C. Mantoura and R.J. Morris. - 1986. Seasonal deposition of phytodetritus to the deep-sea floor. Proc. Roy. Soc. Edinb., 88B: 265-279.

Rice, A.L., D.S.M. Billett, M.H. Thurston and R.S. Lampitt. - 1991 The Institute of Oceanographic Sciences Biology Program in the Porcupine Seabight: background and general introduction. J. Mar. Biol. Ass. UK, 71: 281-310.

Rucabado, J., D. Lloris and C. Stefanescu. - 1991. OTSB14: Un arte de arrastre bentónico para la pesca profunda (por debajo de los mil metros). Inf. Téc. Sci. Mar., 165: 1-27.

Sardà, F., J.E. Cartes, J.B. Company and A. Albiol. - 1998. A modified commercial trawl used to sample deep-sea megabenthos. Fish. Sci., 64: 492-493.

Stefanescu, C., D. Lloris and J. Rucabado. - 1993. Deep-sea assemblages in the Catalan Sea (western Mediterranean) below a depth of 1000 m. Deep-Sea Res., 40: 695-707.

Stefanescu, C., B. Morales-Nin and E. Massutí. - 1994. Fish assemblages on the slope in the Catalan Sea (Western Mediterranean): influence of a submarine canyon. J. Mar. Biol. Ass. UK, 74: 499-512.

Stefanescu, C., J. Rucabado and D. Lloris. - 1992. Depth-size trends in western Mediterranean demersal deep-sea fishes. Mar. Ecol. Prog. Ser., 81: 205-213

Thurston, M.H., B.J. Bett, A.L. Rice and P.A.B. Jackson. - 1994 Variations in the invertebrate abyssal megafauna in the North Atlantic Ocean. Deep-Sea Res., 41: 1321-1348.

Tortonese, E. - 1960. General remarks on the Mediterranean deepsea fishes. Bull. Inst. Océanogr. Monaco, 1167: 1-14.

Underwood, A.J. - 1997. Experiments in ecology. Their logical design and interpretation using analysis of variance. Cambridge University Press, United Kingdom. 
APPENDIX. - Fish species captured in the four studied areas (BB, Balearic basin; AB, Algerian basin; RT, Rockall Trough; PS, Porcupine Seabight), with their bathymetric range $(\mathrm{m})$ and frequency of occurrence $(\%)$ within this depth interval.

\begin{tabular}{|c|c|c|c|c|c|c|c|c|c|}
\hline Family & Species & $\begin{array}{c}\text { BB } \\
\text { Depth }\end{array}$ & $\%$ & $\begin{array}{c}\text { AB } \\
\text { Depth }\end{array}$ & $\%$ & $\begin{array}{c}\text { RT } \\
\text { Depth }\end{array}$ & $\%$ & $\begin{array}{c}\text { PS } \\
\text { Depth }\end{array}$ & $\%$ \\
\hline \multirow{7}{*}{$\begin{array}{l}\text { Myxinidae } \\
\text { Hexanchidae } \\
\text { Scyliorhinidae }\end{array}$} & Myxine ios & & & & & & & $985-1650$ & 33 \\
\hline & Hexanchus griseus & $986-1045$ & 43 & & & & & 960 & - \\
\hline & Apristurus sp. & & & & & $962-1750$ & 81 & $1024-1448$ & 11 \\
\hline & Galeus melastomus & 429-1739 & 71 & $402-1713$ & 79 & $530-582$ & 100 & $506-848$ & 18 \\
\hline & Galeus murinus & & & & & $962-1235$ & & & - \\
\hline & Scyliorhinus canicula & & & 402 & - & & & & \\
\hline & Scymnodon ringens & & & & & $530-775$ & 43 & $706-982$ & 44 \\
\hline \multirow[t]{8}{*}{ Squalidae } & Centrophorus squamosus & & & & & $775-962$ & 50 & 986 & - \\
\hline & Centrophorus uyato ... & & & 802 & - & & & & \\
\hline & Centroscyllium fabricii & & & & & $1032-1545$ & 60 & & \\
\hline & Centroscymnus coelolepis & $1419-1862$ & 58 & $1012-1713$ & 57 & $962-1750$ & 54 & $1027-1720$ & 30 \\
\hline & $\begin{array}{l}\text { Centroscymnus crepidater } \\
\text { Dalatias licha }\end{array}$ & $084-1704$ & 13 & $505-801$ & 40 & $\begin{array}{c}880-1197 \\
530-772\end{array}$ & $\begin{array}{l}72 \\
33\end{array}$ & $545-1360$ & 10 \\
\hline & Deania calceus & $904-1794$ & 13 & $595-891$ & 40 & $582-1032$ & $\begin{array}{l}33 \\
38\end{array}$ & $\begin{array}{c}545-1300 \\
740\end{array}$ & 10 \\
\hline & Etmopterus princeps & & & & & $962-1805$ & 43 & $1533-1720$ & 29 \\
\hline & Etmopterus spinax & $429-1488$ & 45 & $415-1416$ & 82 & 530 & - & $407-1790$ & 14 \\
\hline \multirow[t]{7}{*}{ Rajidae } & Bathyraja richardsoni & & & & & & & 1987 & - \\
\hline & Breviraja caerulea & & & & & $1197-1205$ & 100 & 1390 & - \\
\hline & Raja naevus & & & 908 & - & & & & \\
\hline & $\begin{array}{l}\text { Raja (Dipturus) nidarosiensis } \\
\text { Raja (Leucoraja) circularis }\end{array}$ & & & & & $962-1235$ & 26 & $\begin{array}{c}1263-1312 \\
695\end{array}$ & 40 \\
\hline & Raja (Rajella) bathyphila & & & & & $1450-1870$ & 20 & & \\
\hline & Raja (Rajella) bigelowi & & & & & $1717-1750$ & 100 & $1845-1987$ & 60 \\
\hline & Raja (Rajella) fyllae & & & & & $972-1197$ & 62 & 1024 & 30 \\
\hline \multirow[t]{4}{*}{ Chimaeridae } & Chimaera monstrosa & 1225 & - & & - & $530-1545$ & 94 & $470-1742$ & 38 \\
\hline & Hydrolagus affinis & & & & & $1715-1870$ & 50 & $1720-1993$ & 20 \\
\hline & Hydrolagus mirabilis & & & & & $742-1235$ & 100 & $695-1452$ & 52 \\
\hline & Hydrolagus pallidus & & & & & 1717 & - & & \\
\hline Rhinochimaeridae & Rhinochimaera atlantica ${ }^{1}$ & & & & & 1205 & - & $1360-1533$ & 40 \\
\hline \multirow[t]{12}{*}{ Alepocephalidae } & Alepocephalus agassizii & & & & & $1717-1955$ & 67 & $1650-1993$ & 44 \\
\hline & Alepocephalus australis & & & & & 1485 & - & $1587-1789$ & 37 \\
\hline & Alepocephalus bairdii & & & & & $742-1805$ & 88 & $706-1900$ & 42 \\
\hline & Alepocephalus productus & & & & & & & $1533-1987$ & 30 \\
\hline & Alepocephalus rostratus & $615-1862$ & 100 & $699-1713$ & 90 & $962-1235$ & 47 & $706-1452$ & 56 \\
\hline & Bathytroctes microlepis & & & & & & & $1845-1975$ & 56 \\
\hline & Conocara macroptera & & & & & 1485 & - & $1527-1932$ & 83 \\
\hline & Conocara murrayi & & & & & 1955 & - & $1440-1993$ & 41 \\
\hline & Narcetes stomias & & & & & & & $1867-1900$ & 50 \\
\hline & Photostylus pycnopterus & & & & & & & 1390 & \\
\hline & Rouleina attrita & & & & & $1545-1870$ & 43 & $1312-1927$ & 50 \\
\hline & Xenodermichthys copei & & & & & $582-1870$ & 53 & $577-1975$ & 59 \\
\hline \multirow[t]{2}{*}{ Searsiidae } & Holtbyrnia anomala & & & & & 1717 & - & & \\
\hline & Normichthys operosus & & & & & $1470-1545$ & 67 & & \\
\hline Photichthyidae & Polymetme corythaeola & & & & & & & $472-706$ & 27 \\
\hline Argentinidae & Argentina silus & & & & & $530-582$ & 100 & $407-695$ & 75 \\
\hline Synodontidae & Bathysaurus ferox & & & & & 1870 & - & $1587-1987$ & 53 \\
\hline \multirow[t]{3}{*}{ Chlorophthalmidae } & Bathypterois dubius & & & & & $1197-1545$ & 43 & $986-1900$ & 83 \\
\hline & Bathypterois mediterraneus & $931-1862$ & 93 & $908-1713$ & 100 & & & & \\
\hline & Chlorophthalmus agassizii & & & $402-601$ & 43 & & & & \\
\hline Notosudidae & Scopelosaurus lepidus & & & & & & & $750-1867$ & 10 \\
\hline \multirow[t]{2}{*}{ Nettastomatidae } & Nettastoma melanurum & $651-1078$ & 71 & $415-1416$ & 71 & & & & \\
\hline & Venefica proboscidea & & & & & & & 1527 & - \\
\hline \multirow{8}{*}{$\begin{array}{l}\text { Congridae } \\
\text { Derichthyidae } \\
\text { Synaphobranchidae }\end{array}$} & Conger conger & 831 & - & $693-816$ & 67 & 530 & - & & \\
\hline & Nessorhamphus ingolfianus & & & & & & & 1205 & - \\
\hline & Dysomma brevirostre & $498-615$ & 60 & 601 & - & & & & \\
\hline & Histiobranchus bathybius & & & & & & & $1790-1975$ & 20 \\
\hline & Ilyophis arx & & & & & & & 1789-1900 & 29 \\
\hline & Ilyophis blachei & & & & & $1192-1235$ & 50 & $1284-1789$ & 40 \\
\hline & Ilyophis brunneus & & & & & & & $1533-1884$ & 43 \\
\hline & Synaphobranchus kaupi & & & & & $530-1955$ & 100 & 407-1993 & 99 \\
\hline \multirow{3}{*}{ Haulosauridae } & Aldrovandia sp. & & & & & 985 & & & \\
\hline & Halosauropsis macrochir & & & & & $1717-1955$ & 83 & $1440-1993$ & 78 \\
\hline & Halosaurus johnsonianus & & & & & $1032-1205$ & 40 & $1379-1448$ & 75 \\
\hline Notacanthidae & Notacanthus bonapartei & $498-1862$ & 72 & $595-1513$ & 54 & $530-1955$ & 79 & $470-1975$ & 76 \\
\hline & Notacanthus chemnitzii & & & & & $572-1235$ & 26 & $763-1390$ & 30 \\
\hline & Polyacanthonotus challengeri & & & & & & & $1742-1987$ & 15 \\
\hline & Polyacanthonotus rissoanus & $710-1862$ & 94 & 693-1709 & 38 & 747-1955 & 91 & $740-1993$ & 76 \\
\hline Macrouridae & Coelorhynchus abditilux & & & & & & & $848-1024$ & 22 \\
\hline & Coelorinchus coelorhincus & 532 & - & $402-415$ & 100 & $530-772$ & 83 & $407-1312$ & 23 \\
\hline & Coelorhynchus labiatus & 1049-1844 & 67 & $1012-1713$ & 90 & $747-1870$ & 94 & $472-1900$ & 46 \\
\hline
\end{tabular}

114 E. MASSUTÍ et al. 
APPEndiX (Cont.). - Fish species captured in the four studied areas (BB, Balearic basin; AB, Algerian basin; RT, Rockall Trough; PS, Porcupine Seabight), with their bathymetric range (m) and frequency of occurrence (\%) within this depth interval.

\begin{tabular}{|c|c|c|c|c|c|c|c|c|c|}
\hline Family & Species & $\begin{array}{l}\text { BB } \\
\text { Depth }\end{array}$ & $\%$ & $\begin{array}{c}\text { AB } \\
\text { Depth }\end{array}$ & $\%$ & $\begin{array}{l}\text { RT } \\
\text { Depth }\end{array}$ & $\%$ & $\begin{array}{l}\text { PS } \\
\text { Depth }\end{array}$ & $\%$ \\
\hline \multirow{20}{*}{ Gadidae } & \multicolumn{5}{|l|}{$\begin{array}{l}\text { Coryphaenoides }(C .) \text { brevibarbis } \\
\text { Corvphaenoides }(C .) \text { leptolepis }\end{array}$} & $1750-1955$ & 60 & $\begin{array}{c}1845-1993 \\
1993\end{array}$ & 27 \\
\hline & \multirow{2}{*}{\multicolumn{2}{|c|}{$\begin{array}{l}\text { Coryphaenoides }(C .) \text { mediterraneus } 970-1862 \\
\text { Coryphaenoides }(\text { L.) carapinus }\end{array}$}} & 52 & \multirow[t]{2}{*}{$1094-1713$} & \multirow[t]{2}{*}{83} & \multirow[t]{2}{*}{$1032-1955$} & \multirow[t]{2}{*}{76} & $1272-1993$ & 82 \\
\hline & & & \multirow{3}{*}{93} & & & & & $1742-1975$ & 17 \\
\hline & \multirow{2}{*}{\multicolumn{2}{|c|}{$\begin{array}{l}\text { Coryphaenoides }(C .) \text { guentheri } \\
\text { Coryphaenoides }(C .) \text { rupestris }\end{array}$}} & & $1417-1713$ & 33 & \multirow{3}{*}{$\begin{array}{l}962-1955 \\
530-1870\end{array}$} & \multirow{3}{*}{$\begin{array}{r}73 \\
100\end{array}$} & $1263-1993$ & 94 \\
\hline & & & & & & & & 706-1932 & 72 \\
\hline & \multirow{3}{*}{$\begin{array}{l}\text { Hymenocephalus italicus } \\
\text { Malacocephalus laevis } \\
\text { Nezumia aequalis }\end{array}$} & $429-831$ & 100 & $402-898$ & 100 & & & 472 & - \\
\hline & & & & & & $572-582$ & 100 & $407-512$ & 71 \\
\hline & & $532-1212$ & 96 & $502-1407$ & 100 & $572-1205$ & 92 & $472-1650$ & 66 \\
\hline & Trachyrhynchus murrayi & & & & & $962-1545$ & 74 & $1205-1600$ & 95 \\
\hline & Trachyrhynchhus scabrus & 429-1589 & 73 & $601-816$ & 62 & & & $506-1360$ & 49 \\
\hline & Brosme brosme & & & & & $530-992$ & 19 & & \\
\hline & Gadiculus argenteus & & & $402-601$ & 43 & $530-775$ & 57 & $407-793$ & 32 \\
\hline & Antonogadus macrophthalmus & & & & & $530-1197$ & 31 & $407-1263$ & 26 \\
\hline & Antonogadus megalokynodon & $429-1212$ & 70 & $402-802$ & 83 & & & & \\
\hline & Merluccius merluccius & $710-1075$ & 11 & $402-802$ & 50 & 572 & - & $506-785$ & 29 \\
\hline & Micromesistius poutassou & $429-556$ & 60 & $402-816$ & 43 & $530-1955$ & 23 & $407-804$ & 38 \\
\hline & Molva dypterygia dypterygia & & & & & $530-1470$ & 77 & $490-1257$ & 10 \\
\hline & Molva dypterygia macrophthalma & & & 402 & - & & & $470-695$ & 27 \\
\hline & Molva molva & & & & & 530 & - & & \\
\hline & $\begin{array}{l}\text { Onogadus argentatus } \\
\text { Phycis blennoides } \\
\text { Phycis phycis }\end{array}$ & $429-1308$ & 88 & $402-1032$ & 100 & $530-1012$ & 59 & $\begin{array}{c}1024 \\
407-1027\end{array}$ & 73 \\
\hline Moridae & Antimora rostrata. & & & & & $1192-1955$ & 87 & $982-1993$ & 52 \\
\hline & $\begin{array}{l}\text { Eretmophorus kleinenbergi } \\
\text { Halargyreus johnsonii }\end{array}$ & 931 & - & & & $572-1235$ & 78 & $545-1900$ & 57 \\
\hline & Laemonema latifrons & & & & & & & $985-1867$ & 11 \\
\hline & Lepidion eques & & & & & $530-1235$ & 100 & $506-1524$ & 96 \\
\hline & Lepidion guentheri & $1584-1862$ & 44 & $1591-1713$ & 60 & & & & \\
\hline & Lepidion lepidion & $651-1862$ & 100 & $908-1713$ & 86 & & & & \\
\hline & Mora moro & $532-1589$ & 77 & $693-1305$ & 89 & $530-1007$ & 71 & $500-1312$ & 70 \\
\hline & Rhynchogadus hepaticus & 429 & - & & & & & & \\
\hline Berycidae & Beryx decadactylus & & & & & & & 506 & \\
\hline Trachichthyidae & Hoplostethus atlanticus & & & & & $1032-1235$ & 83 & $960-1677$ & 65 \\
\hline & Hoplostethus mediterraneus & 764 & - & $502-1322$ & 60 & & & $527-848$ & 95 \\
\hline Oreosomatidae & Neocyttus helgae & & & & & & & 1024 & - \\
\hline Apogonidae & Epigonus denticulatus & 429-1008 & 29 & $402-813$ & 46 & & & & \\
\hline & Epigonus telescopus & 970 & - & $802-816$ & 67 & $530-992$ & 56 & $490-1027$ & 50 \\
\hline Trichiuridae & Aphanopus carbo & & & & & $530-1205$ & 52 & $1025-1993$ & 10 \\
\hline & Lepidopus caudatus & & & $402-601$ & 71 & & & & \\
\hline Callionymidae & Synchiropus phaeton & & & $402-543$ & 40 & & & & \\
\hline Zoarcidae & Lycodes atlanticus & & & & & & & $1217-1742$ & 33 \\
\hline & Lycodes crassiceps & & & & & & & $1506-1975$ & 14 \\
\hline & Melanostigma atlanticum & $532-1409$ & 61 & & & $880-1235$ & 65 & 763-1506 & 12 \\
\hline Bythitidae & Cataetyx alleni & $532-1851$ & 91 & $699-1622$ & 26 & & & 1205 & \\
\hline & Cataetyx laticeps & $1739-1862$ & 42 & 1713 & - & $1470-1805$ & 75 & $1440-1993$ & 52 \\
\hline Ophidiidae & Benthocometes robustus & $458-532$ & 67 & & & & & & \\
\hline & Spectrunculus grandis & & & & & 1750-1955 & 80 & 1742-1993 & 71 \\
\hline Aphyonidae & Sciadonus galatheae & & & & & & & 1789 & - \\
\hline Carapidae & $\begin{array}{l}\text { Echiodon drummondi } \\
\text { Echiodon dentatus }\end{array}$ & 429 & - & & & & & $407-545$ & 56 \\
\hline Scorpaenidae & Helicolenus dactylopterus & $429-751$ & $5 \overline{5}$ & $402-543$ & 100 & $530-880$ & 67 & $407-848$ & 67 \\
\hline & $\begin{array}{l}\text { Scorpaena elongata } \\
\text { Sebastes viviparus }\end{array}$ & & & 402 & - & 582 & - & & \\
\hline & Trachyscorpia cristulata echinata & & & & & & & 763-1036 & 72 \\
\hline Triglidae & Trigla lyra & & & 402 & - & & & & \\
\hline Peristediidae & Peristedion cataphractum & & & 402 & - & & & & \\
\hline Psychrolutidae & Cottunculus thomsonii & & & & & $962-1545$ & 39 & $1016-1448$ & 45 \\
\hline Liparididae & Paraliparis caudani & & & & & $747-1197$ & 27 & $695-1016$ & 54 \\
\hline & Paraliparis leptochirus & $615-764$ & 83 & $601-1233$ & 42 & & & & \\
\hline Scophthalmidae & Lepidorhombus boscii & 429-984 & 17 & $415-595$ & 60 & $530-875$ & 50 & $407-785$ & 23 \\
\hline & Lepidorhombus whiffiagonis & & & & & & 100 & & 44 \\
\hline Pleuronectidae & Glyptocephalus cynoglossus & & & & & $530-1197$ & 23 & $407-506$ & 50 \\
\hline Soleidae & Bathysolea profundicola & & & & & & & 527 & - \\
\hline & Microchirus variegatus & & & & & & & 506 & - \\
\hline Cynoglossidae & Symphurus ligulatus & $532-1049$ & 70 & $415-898$ & 87 & & & & \\
\hline & Symphurus nigrescens & $429-615$ & 100 & $402-601$ & 71 & & & & \\
\hline Lophiidae & Lophius piscatorius & $429-1008$ & 10 & & & $742-1032$ & 55 & $407-793$ & 36 \\
\hline & Lophius budegassa & & & 402 & - & & & & \\
\hline
\end{tabular}

${ }^{1}$ For taxonomic composition analysis, this species has been included within the family Chimaeridae. 
